\title{
PEMBERDAYAAN PETANI SAYURAN: KASUS PETANI SAYURAN DI SULAWESI SELATAN
}

\author{
EMPOWERMENT OF VEGETABLE'S FARMERS: \\ CASE STUDY OF VEGETABLE'S FARMERS IN SOUTH SULAWESI
}

\author{
Lukman Hakim dan Basita G. Sugihen
}

\begin{abstract}
This study was focused on analyzing farmers' empowerment and studying factors affecting group dynamic in relation with their business improvement. The objectives of this study were: (1) to identify factors that influence empowerment of crop farmer within groups, (2) the relation between group dynamics and productivity and, (3) the formulation of empowerment strategy through group approach. This study was conducted at two districts area: Gowa and Enrekang at South Sulawesi Province. Primary data were obtained from 240 respondents from members of group farmer who their business mostly cultivate vegetable. Quantitative analysis and qualitative-descriptive analysis were employed to explain the result of the research. Variabels used in the study were individual characteristics. The level of farmer empowerment within group is low, and factors that affect farmers' empowerment within group are low (underdeveloped). These factors are empowerment pattern, level of personality, social environment, information access and level of farmers' productivity. Development of elements of group dynamics in two locations shows low performance that means underdeveloped. The main constraints for developing group dynamics are lack of initiative and participation of group members to encourage group activities, and lack of cooperation and coordination of tasks within group. Individual characteristics include level of formal education, empowerment pattern, farmers' personality, social environment and information access show significantly positive relationship with group dynamic. There are fourteen variabels which positively influence group dynamics. These variabels are empowerment pattern; level of farmers' personality; social environment; and information access. Based on the relationship among variabels in the model of farmer development toward farmer's productivity, it shows that variabels of working network $\left(X_{2.2}\right)$, self confident $\left(X_{3.2}\right)$, culture norms $\left(X_{4.1}\right)$, accurate information $\left(X_{5.2}\right)$, group objective $\left(Y_{1.1}\right)$ and group development $\left(Y_{1.3}\right)$ affect significantly of farmers' productivity. This means these variables have significant role in promoting farmers' productivity. Farmers' productivity is still low and it should be developed through more diynamic activities.
\end{abstract}

Key words : crop farmer, empowerment, group dynamic, and work productivity

\section{Pendahuluan}

Tingkat kehidupan petani belum banyak mengalami perubahan kearah kondisi kehidupan yang lebih baik dalam pembangunan pertanian. Dari 53,1 juta rumah tangga di Indonesia, 24,9 juta adalah rumah tangga tani yang hidup di pedesaan (BPS, 2004). Kemudian dari 36 juta orang penduduk miskin di Indonesia pada tahun 2005, terdapat 25 juta orang atau $69 \%$ adalah petani yang hidup di pedesaan. Hasil survei nasional 
(Susenas) BPS yang dilakukan Maret 2006 mencatat jumlah penduduk miskin mencapai 39,05 juta atau $17,75 \%$ dari total penduduk Indonesia.

Salah satu masalah pertanian nasional secara umum adalah rendahnya kualitas SDM petani, Indonesia. Jika dilihat dari tingkat pendidikan petani Indonesia yang tidak tamat dan tamat SD sebanyak 81,25 persen, tamat SMP sebanyak 13,08 persen, tamat SMA 9,5 persen dan tamat perguruan tinggi sebanyak 0,30 persen (Institut Pertanian Bogor 2003).

Salah satu potensi tanaman pertanian yang perlu diperhatikan dan ditingkatkan pengelolaannya adalah tanaman sayuran. Sasaran produksi hortikultura khususnya sayuran tahun 2006 lebih dari 10 ribu ton. Namun sasaran produksi tersebut kurang berdampak terhadap peningkatan kesejahteraan petani. Oleh sebab itu upaya pemberdayaan petani menjadi penting dengan beberapa alasan antara lain: (1) petani masih dihadapkan pada keterbatasan kemampuan memanfaatkan potensi sumber daya tani yang tersedia, (2) keterbatasan kemampuan mengembangkan usaha pemasaran di mana ketika menghadapi musim panen, produksi meningkat dan harga hasil produksi pun anjlok, dan (3) kemampuan menjalin kerjasama dan kemitraan agribisnis serta kemampuan mengakses modal, akses pasar yang tidak menentu ditambah akses teknologi dan kapasitas manajemen dalam memanfaatkan tenaga kerja yang rendah serta tatanan kelembagaan yang belum sepenuhnya mencapai keseimbangan ideal dalam mengatur interaksi dan pertukaran kepentingan antara stakeholder.

Berdasarkan pemikiran tersebut maka salah satu upaya untuk memberdayakan kehidupan petani adalah dengan mengembangkan usahatani baik on-farm maupun off-farm, mengembangkan jaringan kerja, mengembangkan modal usaha, dan memantapkan kelembagaan penyuluhan melalui kelompok tani agar petani memiliki wadah untuk memperjuangkan kepentingan dan kebutuhan dari kelompok tersebut. Petani yang tergabung dalam kelompok dapat memiliki sejumlah kekuasaan sehingga dapat mengatasi masalah yang dihadapi (Van den Ban dan Hawkins, 1999).

Tujuan dari penelitian ini adalah untuk: (1) menganalisis keberdayaan petani dan kelompok tani, (2) menganalisis faktorfaktor yang berhubungan dengan dinamika kelompok, yaitu faktor pola pemberdayaan, pengembangan kepribadian, lingkungan sosial dan akses pada informasi, (3) menganalisis hubungan dinamika kelompok dengan tingkat produktivitas kerja petani, dan (4) merumuskan strategi pemberdayaan melalui kelompok.

\section{Metode Penelitian}

\section{$\underline{\text { Populasi dan Sampel }}$}

Populasi penelitian ini adalah seluruh petani sayuran anggota kelompok tani di wilayah penelitian yakni kabupaten Gowa dan Enrekang pada empat kecamatan, sebanyak 2.200 orang. Sampel petani sebanyak 240 orang sebagai responden yang terpilih secara acak. Populasi kelompok adalah seluruh kelompok tani di wilayah penelitian yang berjumlah 88 kelompok. Sampel kelompok sebanyak 24 kelompok yang terpilih secara acak.

\section{$\underline{\text { Rancangan Penelitian }}$}

Penelitian ini menganalisis tingkat hubungan dan pengaruh antar peubah independen $(\mathrm{X})$ dengan dinamika kelompok $\left(\mathrm{Y}_{1}\right)$ dan tingkat produktivitas kerja petani $\left(\mathrm{Y}_{2}\right)$. Untuk itu penelitian ini dirancang dalam bentuk explanatory research yang bertujuan menjelaskan pola hubungan dan pengaruh antar peubah melalui pengujian hipotesis. Peubah bebas dalam penelitian ini adalah: karakteristik petani $\left(\mathrm{X}_{1}\right)$, pola pemberdayaan $\left(\mathrm{X}_{2}\right)$, kepribadian petani $\left(\mathrm{X}_{3}\right)$, lingkungan sosial $\left(\mathrm{X}_{4}\right)$, dan akses pada informasi $\left(\mathrm{X}_{5}\right)$. Kemudian peubah terikat adalah: dinamika kelompok $\left(\mathrm{Y}_{1}\right)$, dan tingkat produktivitas kerja petani $\left(\mathrm{Y}_{2}\right)$. 


\section{Data dan Instrumentasi}

\section{$\underline{\text { Data }}$}

Data dan obyek pengamatan dari penelitian ini terdiri dari lima peubah bebas dan dua peubah terikat, yakni : (1) karakteristik individu petani $\left(\mathrm{X}_{1}\right)$, yang dibatasi pada: umur, jenis kelamin, tingkat pendidikan, dan pengalaman berusahatani, (2) pola pemberdayaan $\left(\mathrm{X}_{2}\right)$ yang meliputi: pengembangan kemampuan usaha anggota, pengembangan kemampuan jaringan kerja, dan pelatihan, (3) kepribadian petani $\left(\mathrm{X}_{3}\right)$ yang meliputi: semangat kerja keras, percaya diri, keuletan, dan kreatifitas, (4) lingkungan sosial $\left(\mathrm{X}_{4}\right)$ yang meliputi: norma dan nilai budaya lokal serta peran pemimpin informal, (5) akses pada informasi yang meliputi: relevansi informasi, akurasi informasi, dan ketepatan waktu informasi, (6) dinamika kelompok $\left(\mathrm{Y}_{1}\right)$ yang meliputi: tujuan kelompok, fungsi tugas, pembinaan dan pengembangan kelompok, serta kekompakan kelompok, dan (7) tingkat produktivitas kerja petani $\left(\mathrm{Y}_{2}\right)$ yang meliputi: penyiapan lahan, penyemaian benih, penanaman, pemupukan, pengendalian hama, penanganan hasil panen serta pemasaran hasil produksi.

\section{$\underline{\text { Instrumentasi }}$}

Instrumentasi penelitian berkaitan dengan alat pengukur yang digunakan dalam pengumpulan data penelitian. Instrumen yang dipersiapkan untuk mengumpulkan data penelitian ini adalah kusioner yang berisi butir-butir pertanyaan yang berhubungan dengan peubah/variabel penelitian. Kusioner tersebut berisi pertanyaan tertutup di mana jawaban sudah ditentukan terlebih dahulu, dan terdapat pula pertanyaan yang bersifat terbuka di mana responden diberi kesempatan memberi jawaban lain.

Hasil uji validitas item instrumen ( $r$ hitung) berkisar 0,091 s.d 0,740 pada taraf signifikan 95\%. Dengan demikian instrumen yang digunakan cukup valid. Hasil uji realibilitas instrumen dengan metode Cronbach Alpha diperoleh koefisien sekitar 0,377 s.d 0,981 atau instrumen dianggap cukup reliabel sebagai alat ukur.

\section{Pengumpulan Data}

Data penelitian yang akan diambil terdiri dari data primer dan data sekunder. Data primer yang berasal dari data lapangan (responden) dikumpulkan dengan menggunakan kuesioner baik yang bersifat tertutup maupun yang bersifat terbuka.

Pengumpulan data dilakukan dengan teknik wawancara. Untuk memperkuat objektivitas data dilakukan pula pengamatan dan wawancara bebas dengan tetap terfokus pada pertanyaan penelitian. Sedangkan data sekunder bersumber dari dokumentasi instansi terkait serta hasil studi kepustakaan.

Selain responden sampel, informasi diperoleh pula dari sejumlah informan. Informan adalah pihak yang berperan memberikan informasi tentang kebijakan pemberdayaan dan kegiatan petani serta informasi tentang budaya lokal di lokasi penelitian.

\section{$\underline{\text { Analisis Data }}$}

Penelitian ini menganalisis berbagai bentuk hubungan antar peubah sekaligus menguji hipotesis, yakni: (1) untuk menganalisis hubungan antar variabel $X$ maupun hubungan variabel $\mathrm{X}$ dan $\mathrm{Y}$, digunakan analisis korelasi Kendall's dan rank Spearman, (2) untuk menguji perbedaan dua sampel independen digunakan uji MannWhitney, dan perbedaan keragaman dua sampel dependen digunakan uji One Way Anova, (3) untuk menganalisis hubungan antara berbagai variabel $\mathrm{X}$ dengan $\mathrm{Y}$ menggunakan analisis regresi linier berganda, (4) untuk memperluas analisis antar peubah digunakan analisis jalur (path analysis). 


\section{Hasil dan Pembahasan}

\section{$\underline{\text { Hasil }}$}

Umur responden rata-rata 40 tahun. Responden yang berumur produktif antara 16 - 39 tahun sebanyak 46,2 persen, dan yang berumur akhir masa produktif lebih dari 49 tahun sebanyak 53,8 persen. Usia produktif petani menggambarkan sebagai suatu potensi yang handal untuk diberdayakan dan dikembangkan dalam memajukan usaha tanaman sayuran di masa yang akan datang.

Mayoritas petani atau 56,3 persen telah mengenyam pendidikan lebih dari 6 tahun atau tamat Sekolah Dasar. Hal ini suatu indikasi bahwa tingkat pengetahuan dan kualitas wawasan petani masih tergolong rendah. Dari segi pengalaman usaha, mayoritas petani atau 55,0 persen memiliki pengalaman usaha lebih dari 7 tahun. Hal ini menunjukkan bahwa separuh jumlah responden telah memiliki pengalaman yang cukup dan perlu ditingkatkan kualitas pengalaman usahanya agar semakin mampu meningkatkan produktivitas kerja.
Luas lahan yang dikuasai responden rata-rata 0,9 ha, dan pendapatan dari hasil usahatani rata-rata Rp. 203.343,-/bulan. Pendapatan di luar kegiatan usahatani ratarata Rp. 269.811/bulan. Kondisi tersebut menggambarkan masih rendahnya pendapatan petani dan semakin sulitnya memperoleh tingkat penghidupan yang layak serta keluar dari kemiskinan dalam menjalani kehidupannya.

\section{Keberdayaan Petani}

Secara umum keberdayaan petani dalam kelompok di dua lokasi penelitian tergolong rendah. Hal tersebut terlihat, selain karena masih rendahnya tingkat pendapatan usahatani yang diperoleh juga karena masih rendahnya kemampuan mengembangkan unsur-unsur dinamika dalam kelompok. Di antara empat unsur dinamika kelompok, unsur yang masuk kategori terendah adalah pengembangan fungsi tugas, dan unsur pembinaan/pengembangan kelompok di kedua lokasi seperti terlihat dalam Tabel 1.

Tabel 1. Sebaran Persepsi Responden Menurut Pengembangan Dinamika Kelompok

\begin{tabular}{|c|c|c|c|c|c|c|c|}
\hline \multirow{3}{*}{$\begin{array}{c}\text { Unsur } \\
\text { Dinamika Kelompok }\end{array}$} & \multirow[t]{3}{*}{ Kriteria } & \multicolumn{4}{|c|}{ Kabupaten } & \multirow{2}{*}{\multicolumn{2}{|c|}{ Total }} \\
\hline & & \multicolumn{2}{|c|}{ Gowa } & \multicolumn{2}{|c|}{ Enrekang } & & \\
\hline & & $\mathrm{n}$ & $\%$ & $\mathrm{n}$ & $\%$ & $\mathrm{n}$ & $\%$ \\
\hline \multirow{3}{*}{ Tujuan Kelompok } & Rendah & 80 & 66,7 & 42 & 35,0 & 122 & 50,8 \\
\hline & Tinggi & 40 & 33,3 & 78 & 65,0 & 118 & 49,2 \\
\hline & Jumlah & 120 & 100,0 & 120 & 100,0 & 240 & 100,0 \\
\hline \multirow{3}{*}{ Fungsi Tugas } & Rendah & 80 & 66,7 & 48 & 40,0 & 128 & 53,3 \\
\hline & Tinggi & 40 & 33,3 & 72 & 60,0 & 112 & 46,7 \\
\hline & Jumlah & 120 & 100,0 & 120 & 100,0 & 240 & 100,0 \\
\hline \multirow{3}{*}{$\begin{array}{l}\text { Pembinaan dan Pengembangan } \\
\text { Kelompok }\end{array}$} & Rendah & 82 & 68,4 & 45 & 37,5 & 127 & 53,0 \\
\hline & Tinggi & 38 & 31,6 & 75 & 62,5 & 113 & 47,0 \\
\hline & Jumlah & 120 & 100,0 & 120 & 100,0 & 240 & 100,0 \\
\hline \multirow{3}{*}{ Kekompakan Kelompok } & Rendah & 85 & 70,8 & 36 & 30,0 & 121 & 50,4 \\
\hline & Tinggi & 35 & 29,2 & 84 & 70,0 & 119 & 49,6 \\
\hline & Jumlah & 120 & 100,0 & 120 & 100,0 & 240 & 100,0 \\
\hline \multirow{3}{*}{ Dinamika Kelompok } & Rendah & 78 & 65,0 & 45 & 37,5 & 123 & 51,3 \\
\hline & Tinggi & 42 & 35,0 & 75 & 62,5 & 117 & 48,7 \\
\hline & Jumlah & 120 & 100,0 & 120 & 100,0 & 240 & 100,0 \\
\hline
\end{tabular}

Sumber : Data Primer, diolah 2007 Rendah = Kurang dikembangkan $\quad$ Tinggi = Dik embangkan Uji One Way Anova, berbeda nyata pada dua lokasi $\alpha=0,05 \mathrm{P}=0,000 \mathrm{~F}$ hit $=41,355$. 


\section{Faktor-Faktor Eksternal yang Berhubungan dengan Dinamika Kelompok}

Kemampuan petani mengembangkan faktor-faktor eksternal yang berhubungan dengan dinamika kelompok tergolong rendah (kurang dikembangkan). Seperti faktor pola pemberdayaan, pengembangan kepribadian, lingkungan sosial, akses informasi dan tingkat produktivitas kerja seperti terlihat pada Tabel 2.

Tabel 2. Sebaran Responden Menurut Pola Pemberdayaan, Tingkat Kepribadian, Lingkungan Sosial dan Akses pada Informasi dan Tingkat Produktivitas Kerja

\begin{tabular}{|c|c|c|c|c|c|c|c|}
\hline \multirow{3}{*}{ Peubah } & \multirow{3}{*}{ Kriteria } & \multicolumn{4}{|c|}{ Kabupaten } & \multirow{2}{*}{\multicolumn{2}{|c|}{ Total }} \\
\hline & & \multicolumn{2}{|c|}{ Gowa } & \multicolumn{2}{|c|}{ Enrekang } & & \\
\hline & & $\mathrm{n}$ & $\%$ & $\mathrm{n}$ & $\%$ & $\mathrm{n}$ & $\%$ \\
\hline \multirow[t]{3}{*}{ Pola Pemberdayaan } & Rendah & 55 & 45,8 & 65 & 54,2 & 120 & 50,0 \\
\hline & Tinggi & 64 & 54,2 & 55 & 45,8 & 120 & 50,0 \\
\hline & Jumlah & 120 & 100,0 & 120 & 100,0 & 240 & 100,0 \\
\hline \multirow{3}{*}{ Tingkat Kepribadian } & Rendah & 71 & 59,2 & 57 & 47,5 & 128 & 53,3 \\
\hline & Tinggi & 49 & 40,8 & 63 & 52,5 & 112 & 46,7 \\
\hline & Jumlah & 120 & 100,0 & 120 & 100,0 & 240 & 100,0 \\
\hline \multirow{3}{*}{ Lingkungan Sosial } & Rendah & 64 & 53,3 & 56 & 46,7 & 120 & 50,0 \\
\hline & Tinggi & 56 & 46,7 & 64 & 53,3 & 120 & 50,0 \\
\hline & Jumlah & 120 & 100,0 & 120 & 100,0 & 240 & 100,0 \\
\hline \multirow{3}{*}{ Akses Pada Informasi } & Rendah & 53 & 44,2 & 67 & 55,8 & 120 & 50,0 \\
\hline & Tinggi & 67 & 55,8 & 53 & 44,2 & 120 & 50,0 \\
\hline & Jumlah & 120 & 100,0 & 120 & 100,0 & 240 & 100,0 \\
\hline \multirow{3}{*}{ Tingkat Produktivitas Kerja } & Rendah & 68 & 56,7 & 54 & 45,0 & 122 & 50,8 \\
\hline & Tinggi & 52 & 43,3 & 66 & 55,0 & 118 & 49,2 \\
\hline & Jumlah & 120 & 100,0 & 120 & 100,0 & 120 & $\overline{100,0}$ \\
\hline
\end{tabular}

Sumber : Data Primer diolah, 2007

Rendah $=$ Kurang dikembangkan $\quad$ Tinggi $=$ Dikembangkan

Uji Mann-Whitney secara nyata tidak berbeda pada dua lokasi pada $\alpha=0,05$

\section{Hubungan antar Peubah Terhadap Dinamika Kelompok dan Tingkat Produktivitas Kerja}

Hasil uji korelasi (Tabel 3) menunjukkan, faktor karakteristik individu yakni; umur dan pengalaman usahatani berhubungan negatif dengan dinamika kelompok dan tingkat produktivitas kerja, artinya faktor umur dan pengalaman usahatani kurang mampu meningkatkan kegiatan kelompok dan peningkatan produktivitas kerja petani. Tingkat pendidikan petani, faktor pola pemberdayaan, faktor tingkat kepribadian, lingkungan sosial dan akses pada informasi berhubungan positif dan nyata dengan dinamika kelompok dan tingkat produktivitas kerja petani, artinya aktifitas kelompok dan peningkatan produktivitas kerja petani dapat dikembangkan dengan tingkat pendidikan formal petani, efektivitas pola pemberdayaan, kualitas kepribadian, tekanan lingkungan sosial, dan kemampuan petani mengakses informasi berdasarkan usaha yang dikembangkan.

Hasil uji persamaan regresi (Tabel 3) menunjukkan bahwa faktor umur dan pengalaman usahatani berpengaruh negatif terhadap dinamika kelompok dan tingkat produktivitas kerja. 
Tabel 3 Nilai Koefisien Korelasi Spearman dan Koefisien Regresi antar Peubah Bebas dengan Dinamika Kelompok dan Tingkat Produktivitas Kerja

\begin{tabular}{|l|c|c|c|c|}
\hline \multirow{2}{*}{ Variabel Independen $(\mathrm{X})$} & \multicolumn{2}{|c|}{ Koefisien Korelasi } & \multicolumn{2}{c|}{ Koefisien Regresi } \\
\cline { 2 - 5 } & $\mathrm{Y}_{1}$ & $\mathrm{Y}_{2}$ & $\mathrm{Y}_{1}$ & $\mathrm{Y}_{2}$ \\
\hline & & & & $-0,127^{*}$ \\
Umur $\left(\mathrm{X}_{11}\right)$ & $-0,218^{* *}$ & $-0,079$ & 0,032 \\
Tingkat Pendidikan $\left.\mathrm{X}_{12}\right)$ & $0,246^{* *}$ & 0,060 & 0,057 & 0,037 \\
Pengalaman Usahatani $\left.\mathrm{X}_{13}\right)$ & $-0,357^{* *}$ & $-0,251$ & $-0,033$ & $-0,079$ \\
Pola Pemberdayaan $\left(\mathrm{X}_{2}\right)$ & $0,621^{* *}$ & 0.558 & $0,184^{*}$ & 0,201 \\
Tingkat Kepribadian $\left(\mathrm{X}_{3}\right)$ & $0,527^{* *}$ & 0,599 & $0,098^{*}$ & 0,355 \\
Lingkungan Sosial $\left(\mathrm{X}_{4}\right)$ & $0,645^{* *}$ & 0,389 & $0,499^{* *}$ & 0,099 \\
Akses Pada Informasi $\left(\mathrm{X}_{5}\right)$ & $0,627^{* *}$ & 0,393 & 0,139 & 0,025 \\
& & & & \\
\hline
\end{tabular}

Keterangan:. * nyata pada $\alpha=0,05 \quad * *$ nyata pada $\alpha=0,01$

$$
\mathrm{Y}_{1}=\text { Dinamika kelompok } \quad \mathrm{Y}_{2}=\text { Produktivitas kerja }
$$

Hal ini berarti faktor umur kurang berkualitas mendorong berkembangnya keberdayaan petani dalam kelompok dan peningkatan produktivitas kerja. Kemudian pola pemberdayaan, pengembangan kepribadian, lingkungan sosial dan akses pada informasi berpengaruh positif terhadap dinamika kelompok dan tingkat produktivitas kerja petani. Hal ini dapat dijelaskan bahwa keberdayaan petani dalam kelompok dapat dikembangkan dengan meningkatkan kualitas pola pemberdayaan, pengembangan kepribadian, kedinamisan lingkungan sosial dan kemampuan mengakses informasi. Dengan demikian jika peubah-peubah tersebut berada dalam kondisi yang meningkat maka akan semakin baik pula pengembangan dinamika kelompok dan tingkat produktivitas kerja petani.

Hasil uji regresi menunjukkan pula bahwa dinamika kelompok berpengaruh positif dan nyata terhadap tingkat produktivitas kerja petani dengan koefisien regresi sebesar 0,305. Artinya kegiatan pemberdayaan dengan meningkatkan produktivitas kerja petani dapat dikembangkan melalui kegiatan kelompok tani. Semakin meningkat aktivitas kelompok tani maka produktivitas kerja petani juga akan semakin meningkat terutama dalam aktifitas budidaya tanaman sayuran.

Berdasarkan diagram analisis jalur yang ditampilkan pada Gambar 2 berupa hubungan antara berbagai unsur-unsur peubah bebas dan dinamika kelompok dengan tingkat produktivitas kerja petani menunjukkan adanya enam jalur hubungan antar peubah yang mempunyai koefisien jalur yang signifikan terhadap tingkat produktivitas kerja petani. Jalur tersebut adalah: (1) jalur hubungan langsung antar peubah $\mathrm{X}$ terhadap tingkat produktivitas kerja petani dengan nilai $\mathrm{R}^{2}$ sebesar 0,432; (2) jalur hubungan tidak langsung melalui peubah pengembangan jaringan kerja dengan nilai $\mathrm{R}^{2}$ sebesar 0,730 ; (3) jalur hubungan tidak langsung melalui peubah percaya diri dengan nilai $\mathrm{R}^{2}$ sebesar 0,553; (4) jalur hubungan tidak langsung melalui peubah norma dan nilai budaya dengan nilai $\mathrm{R}^{2}$ sebesar 0,439; (5) jalur hubungan tidak langsung melalui peubah tujuan kelompok dengan nilai $\mathrm{R}^{2}$ sebesar 0,696; dan (6) jalur hubungan tidak langsung melalui peubah pembinaan dan pengembangan kelompok dengan nilai $\mathrm{R}^{2}$ sebesar 0,652. Model jalur hubungan tersebut memiliki Goodness of Fit Index (GFI) sebesar 0,852 . Artinya semakin tinggi nilai tersebut atau semakin mendekati angka satu berarti model memiliki kesesuaian dengan realitas yang diwakili oleh data yang relatif baik.

Peubah tujuan kelompok yang berpengaruh negatif terhadap tingkat produktivitas kerja petani mengindikasikan bahwa rumusan tujuan kelompok yang bersifat formal kurang mampu diimplementasikan oleh petani terutama 
dalam meningkatkan kinerjanya. Keberadaan kelompok masih lebih dominan untuk mencapai tujuan yang bersifat informal sebagai wadah untuk menjalin pertemuanpertemuan kekerabatan dan pertemuan/ silaturrahim lainnya. Tujuan kelompok yang berpengaruh negatif tersebut disebabkan oleh tujuan kelompok itu sendiri belum mampu dirumuskan secara baik dan berkualitas oleh petani.

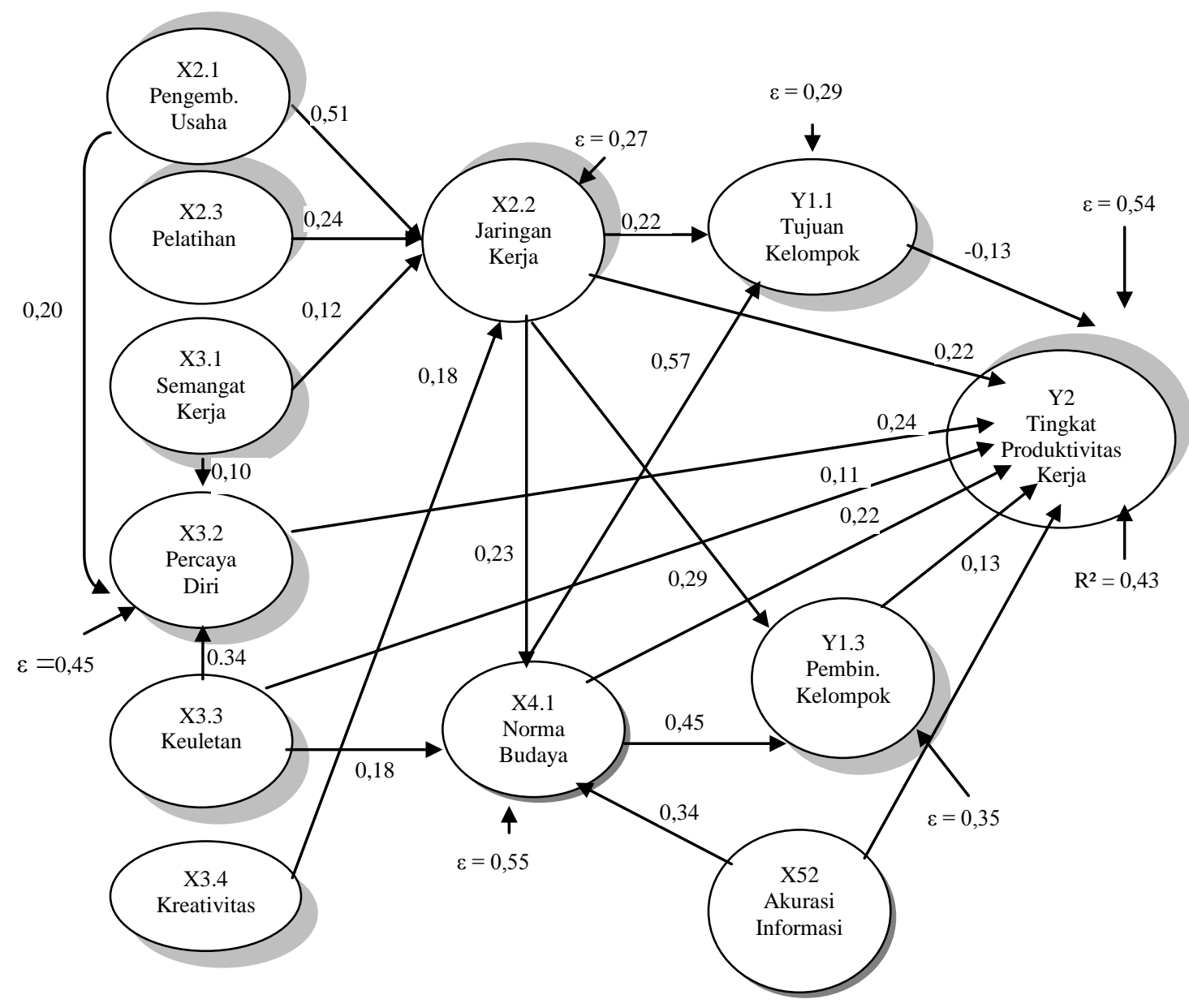

Gambar 2: Jalur Hubungan antar Peubah Bebas Terhadap Tingkat Produktivitas Kerja Petani Keterangan: $\mathrm{R}^{2}=$ koefisien determinasi hubungan langsung seluruh peubah bebas

\section{$\underline{\text { Pembahasan }}$}

Dalam kaitan dengan penelitian ini maka kekurangberdayaan petani sayuran di lokasi penelitian tidak terlepas dari akar permasalahan yakni masalah kemiskinan. Penyebab langsung kekurangberdayaan petani terkait dengan rendahnya tingkat produktivitas kerja yang berimplikasi terhadap rendahnya tingkat pendapatan. Rendahnya tingkat pendidikan serta kualitas pengalaman usahatani berimplikasi terhadap minimnya kualitas pengetahuan dan keterampilan. Rendahnya semangat dan keuletan berusahatani yang berimplikasi terhadap menurunnya kemampuan mengembangkan usaha, merupakan rangkaian permasalahan yang membuat kehidupan petani semakin terpuruk.

Kekurangberdayaan petani disebabkan pula oleh beberapa faktor penyebab tidak langsung seperti minimnya modal usaha, kurang efektifnya penyuluhan, pelatihan, rendahnya kualitas penyuluh dan 
kekurangmampuan mengakses informasi usaha. Rendahnya kemampuan petani dalam persaingan usaha dengan kelompok produsen agribisnis, merupakan rentetan penyebab kekurangberdayaan petani dalam meningkatkan tingkat pendapatannya. Selain itu rendahnya peran swasta, minimnya perhatian pemerintah serta kurang dinamisnya sebagian unsur-unsur lingkungan sosial menjadikan kehidupan petani semakin kurang berdaya.

Implikasi masalah tersebut akan menjadikan kehidupan petani semakin terpuruk, daya saing rendah, jumlah dan mutu produksi rendah dan sulit mengembangkan usaha. Oleh karena itu berdasarkan analisis dalam penelitian ini maka perlu dikembangkan kemampuan usaha petani, kemampuan membangun jaringan kerja dan pelatihan. Semangat kerja dan kreativitas petani akan meningkat jika terbuka akses mengembangkan jaringan kerja khususnya jaringan permodalan dan pemasaran. Selain itu spirit norma dan nilai budaya serta peningkatan layanan informasi khususnya bagi petani yang berdomisili di wilayah terpencil dan jauh dari pusat informasi pembangunan pertanian perlu mendapat perhatian.

Besaran pengaruh lingkungan sosial khususnya norma dan nilai budaya lokal menunjukkan bahwa keberhasilan mengelola program dan tujuan kelompok dan peningkatan produktivitas kerja petani adalah dengan tanpa mengabaikan tradisi, nilai-nilai sosial budaya, adat kebiasaan, kepercayaan dan kebutuhan-kebutuhan yang dirasakan dalam lingkungan sosial sekitarnya.

Agar nilai-nilai sosial budaya dapat dikembangkan secara berkualitas diperlukan analisis sosial untuk mengetahui faktor-faktor sosial budaya mana yang berpengaruh secara signifikan dan dapat dikembangkan secara positif sesuai dengan tujuan kelompok. Sejalan dengan hal tersebut, Edi Suharto (2005) menyatakan dalam memahami masyarakat perlu memahami nilai-nilai dominan yang meliputi: (a) apa nilai-nilai budaya, tradisi, atau keyakinan-keyakinan yang penting bagi pengembangan masyarakat?, (b) apa nilai-nilai dominan yang mempengaruhi populasi sasaran dalam masyarakat?, (c) kelompok-kelompok dan individu manakah yang menganut nilai-nilai tersebut dan siapa yang menentangnya, dan (d) apa konflik-konflik nilai yang terjadi pada populasi sasaran? Dengan memahami nilainilai budaya dalam masyarakat tersebut akan meminimalisasi ketegangan-ketegangan sosial dalam mengelola kelompok.

Responden petani dan kelompok tani berada dalam komunitas pedesaan yang sarat dengan perilaku-perilaku yang masih tradisionil. Misalnya dalam pengambilan keputusan, petani terkadang sulit menerima perbedaan pendapat karena nilai kekerabatan, solidaritas dan ketaatan kepada tokoh dan pemimpin informal masih dominan. Nilai kekerabatan dan solidaritas kekeluargaan tersebut merupakan ciri-ciri sosial masyarakat desa.

Susanto (1985) mendeskripsikan ciriciri sosial masyarakat desa antara lain: (1) rasa persatuan yang lebih erat dan hubungan yang lebih akrab di antara warga satu komunitas dari pada hubungan mereka dengan warga masyarakat lain di luar batas wilayahnya; (2) sistem kehidupan berkelompok, atas dasar sistem kekeluargaan, maka ada keseragaman (homogenitas) penduduk berdasarkan darah keturunan; (3) dari sudut permasalahannya, hubungan antara penguasa dengan rakyatnya berlangsung secara informal atas dasar musyawarah.

Seorang pemimpin sering mempunyai beberapa kedudukan dan peranan macammacam yang tumpang tindih, tidak ada pembagian bidang yang jelas; (4) kontrol atau pengendalian sosial atas perilaku warga sangat ketat sehingga relatif sulit terjadi perubahan-perubahan. Dengan demikian terjadi homogenitas dalam perilaku dan cara berpikir; dan (5) mobilitas sosial horizontal maupun vertikal masih jarang. Keterikatan pada adat kebiasaan relatif ketat karena peran golongan orang-orang tua/sesepuh setempat yang menonjol, dalam penelitian ini disebut sebagai tokoh informal. Biasanya golongan 
orang-orang tua ini justru mempunyai pandangan yang didasarkan pada tradisi. Dengan demikian lalu terjadi keseragaman dalam bidang kebudayaan.

Berdasarkan ciri-ciri tersebut mengindikasikan bahwa hubungan kelompok tani dengan norma dan nilai budaya lokal serta dengan peran tokoh informal merupakan hal yang saling mempengaruhi sehingga memiliki saling keterikatan dalam mengembangkan dan memajukan usaha kelompok secara harmonis. Namun dalam perkembangan suatu kelompok yang lebih dinamis menuntut perlunya suatu tatanan kehidupan sosial budaya yang lebih modern tanpa mengabaikan norma dan nilai budaya lokal yang positif.

\section{$\underline{\text { Strategi Pemberdayaan }}$}

Keberdayaan petani akan berkembang bila didukung oleh kekuatan kelompok khususnya kemampuan mengembangkan tujuan dan pembinaan kelompok. Dengan demikian keberdayaan petani dapat dilakukan melalui penguatan strategis yang dilaksanakan secara terpadu yakni: (1) penguatan pemberdayaan melalui pengembangan usaha, pelatihan, peningkatan semangat kerja dan kreativitas, dan akan lebih kuat jika di dukung atau dipadukan dengan kemampuan petani mengembangkan jaringan kerja, terutama jaringan permodalan dan jaringan pemasaran hasil produk, (2) penguatan pemberdayaan melalui pengembangan usaha, semangat kerja, dan keuletan, akan lebih kuat jika di dukung oleh peningkatan rasa percaya diri petani, (3) penguatan kemampuan mengakses informasi, khususnya informasi yang terpercaya dan didorong oleh semangat dari norma dan nilai budaya dan (4) penguatan kemampuan mengembangkan jaringan kerja dan norma budaya melalui pembinaan kelompok.

Pentingnya peran kelompok, diadopsi dari model strategi pemberdayaan. Parsons et al. (1994) menyatakan bahwa proses pemberdayaan umumnya dilakukan secara kolektif melalui kelompok. Melalui kelompok, petani melakukan interaksi terus menerus dengan lingkungannya dalam membangun potensi dirinya, rasa percaya diri dan termotivasi menjauhkan sikap keterasingan dari semua layanan akses dan sumber-sumber pendukung usaha.

Melalui kelompok, petani belajar mengelola kemampuan dirinya yang tumbuh dan berkembang menjadi sebuah perubahan sosial yang lebih besar atau dari keadaan psikologis yang ditandai oleh kurangnya rasa percaya diri menjadi berguna dan mampu mengendalikan diri dan orang lain. Namun dalam beberapa situasi, strategi pemberdayaan dapat saja dilakukan secara individual, meskipun pada gilirannya tetap berkaitan dengan kolektivitas.

Dalam konteks ilmu penyuluhan, proses pemberdayaan dapat dilakukan dengan pendekatan individu atau dalam relasi (antara petani dengan penyuluh) dalam setting pertolongan perseorangan. Pemberdayaan yang dilakukan terhadap klien secara individu melalui bimbingan, dilakukan dengan cara belajar orang dewasa yang tujuan utamanya adalah membimbing, mendidik atau melatih klien agar lebih tahu, mau dan mampu merubah perilaku untuk meningkatkan kesejahteraannya.

\section{$\underline{\text { Kesimpulan }}$}

Berdasarkan analisis dan pembahasan, maka dirumuskan beberapa kesimpulan berikut:

(1)Tingkat keberdayaan petani dalam kelompok tergolong rendah. Hal tersebut selain karena masih rendahnya tingkat pendapatan usahatani yang diperoleh juga karena masih rendahnya kemampuan mengembangkan pola pemberdayaan, tingkat kepribadian, lingkungan sosial dan akses pada informasi. Pengembangan unsur-unsur dinamika kelompok tani juga kurang dikembangkan. Kelemahan utama dalam mengembangkan dinamika kelompok adalah kurangnya inisiatif dan 
partisipasi anggota dalam menggerakkan kegiatan kelompok serta lemahnya kerjasama dan kordinasi tugas dalam kelompok.

(2) Tingkat pendidikan formal, pola pemberdayaan yang efektif, pengembangan kepribadian yang berkualitas, lingkungan sosial yang dinamis dan akses informasi yang tinggi merupakan faktor yang berhubungan dan berpengaruh secara signifikan dalam meningkatkan keberdayaan petani dalam kelompok. Jika faktor-faktor tersebut berjalan efektif maka keberdayaan petani dalam kelompok akan semakin meningkat sebagai wadah pembinaan, pembelajaran dan peningkatan kemampuan usahatani.

(3) Tingkat produktivitas kerja petani dipengaruhi langsung oleh faktor jaringan kerja, percaya diri, norma budaya, akurasi informasi, tujuan dan pembinaan kelompok. Oleh sebab itu strategi pemberdayaan petani dapat dikembangkan secara terpadu antara pengembangan usaha, pelatihan, semangat kerja, kreatifitas dengan kemampuan mengembangkan jaringan kerja. Demikian pula pengembangan akses informasi dapat berhasil jika didukung oleh adanya informasi yang akurat (terpercaya) yang diperoleh petani dalam mengembangkan usahanya, serta didukung oleh spirit norma dan nilai budaya yang dinamis.

(4) Peran kelompok dalam meningkatkan produktivitas kerja petani kurang berkembang dan kurang mampu dikembangkan secara optimal oleh petani.

\section{$\underline{\text { Rujukan }}$}

Adi, Isbandi R. 2003. Pemberdayaan Pengembangan Masyarakat dan Intervensi Komunitas. Jakarta: Lembaga Penerbit Fakultas Ekonomi Universitas Indonesia

Arifin, B. 2004. Analisis Ekonomi Pertanian Indonesia. Jakarta: Penerbit Buku Kompas
Biro Pusat Statistik. 2005. Pelaksanaan Pendataan Rumah Tangga Miskin. Jakarta: Biro Pusat Statistik

Edi Suharto. 2005. Membangun Masyarakat Memberdayakan Rakyat. Bandung: Refika Aditama

Kusmaryadi. 2004. Statistika Pariwisata Deskriptif. Jakarta: Gramedia

Lau, James B, and A.B. Shani. 1992. Behavior in Organizations An Experiential Approach. Boston: Irwin.

Margono Slamet. 2003. Membentuk Pola Perilaku Manusia Pembangunan. Bogor: IPB Press

Mosher, A.T. 1983. Menggerakkan dan Membangun Pertanian. Disadur oleh: S. Krisnandi dan Bahrin Samad. Jakarta: C.V. Yasaguna.

Mubyarto. 1995. Pengantar Ekonomi Pertanian. Jakarta: LP3ES

Ohama, Yutaka. 2002. Participatory Local Social Development. Nagoya: JICA

Sayogyo, dan Pudjiwati Sayogyo (Penyunting). 2002. Sosiologi Pedesaan: Kumpulan Bacaan. Yokyakarta: Gadjah Mada University Press

Saragih, B. 2001. Agribisnis, Paradigma Baru Pembangunan Ekonomi Berbasis Pertanian. Bogor: Pustaka Wirausaha Muda

Sarwono, S.W. 2001. Psikologi Sosial. Jakarta: Balai Pustaka

Singarimbun, Sofian E. 1989. Metode Penelitian Survai. Jakarta: LP3ES

Soesanto, A. 1985. Pengantar Sosiologi dan Perubahan Sosial. Jakarta: Bina Cipta.

Supranto. 2004. Analisis Multivariat: Arti dan Interpretasi. Jakarta: Rineka Cipta

Uphoff, N. 1988. Local Institutional Development. Fransisco: Cornell University Press

van den Ban, A.W, and H.W. Hawkins. 1999. Penyuluhan Pertanian. (Terjemahan) Oleh: Agnes Dwina Herdiasti. Yokyakarta: Penerbit Kanisius. 